\title{
Chemical Weapons: The United Nations Team of Experts in the Iran-Iraq War
}

\author{
Col. Dr. U. Imobersteg*
}

\begin{abstract}
This report from a member of the United Nations (UN) team of experts describes the investigations of the use of chemical weapons during the Iran-Iraq War. The UN-sponsored team of experts discovered evidence that clearly showed the use of three chemical weapon substances during that conflict-Yperite (Mustard Gas), Tabun (nerve gas), and Phosgene (respiratory irritant). The effects of these chemical agents and some means of treatment for victims are described.
\end{abstract}

\section{Introduction}

Following the grisly results of the chemical warfare which marked World War I, a Geneva Protocol was concluded in 1925 which outlawed the first use of this means of mass destruction. The Protocol, however, permits the manufacture and storage of chemical weapons. Such substances were not employed during World War II, despite the fact that both sides had large supplies in a state of operational readiness. More recently, it has been only in "local" conflicts-Vietnam, Yemen, Afghanistan-that chemical substances have been brought back to use.

In late 1983 and early 1984, the Islamic Republic of Iran accused its opponent Iraq of having used certain poisonous chemicals against its Revolutionary Guards, and the problem was brought before the United Nations Security Council. In the spring of 1984, the Secretary General of the United Nations (UN) decided to assemble a group of specialists who, for the first time in a combat zone, would investigate the truth of such allegations. The team, as a whole, was to be responsible directly to the Secretary General. In March 1984, this group, accompanied by a coordinator from the UN Secretariat, made its first venture into the Persian Gulf. It was charged with:

1. the inspection of those areas in which attacks with chemical weapons presumeably had taken place, the conduct of field analyses, and, if possible, the collection fragments of used munition;

2. the examination of evidence provided to the team of experts by third persons, and through examinations of eyewitnesses as to time, place, and circumstances of attacks with chemical weapons; and

3. the questioning and medical examination of victims of chemical attacks, including, where possible, the performance of or examination of records of pertinent postmortem examinations and the securing of relevant tissue samples.

The same assignment was given to the subsequent investigative teams in 1986, in April 1987, and in the summer of 1988.

\section{Methods}

In 1984 and 1986, presumed victims of such attacks were examined medically in hospitals in Alwaz and Teheran, Iran. Samples were collected in the southwestern combat zone, in the Howezieh Swamps, and the area around Abadan, and were analyzed using mass spectog- raphy and gas chromatography by the AC Laboratories in Spiez, Switzerland, and the FOA Laboratory in Ume, Sweden.

The tour of inspection in April 1987 was launched as a result of new allegations, this time coming from both Baghdad, Iraq, and Teheran, Iran. This made it possible for the team of experts

\footnotetext{
* Swiss Army Toxicology Section, Consultant to the United Nations, Geneva, Switzerland.

Presented at the Round Table on the Implications of Chemical/Biological Weapons on Man, Society, and the Environment, organized jointly by the Medical Society of the World Health Organization (WHO), the World Association for Emergency and Disaster Medicine, The Round Table presentation took place at WHO, Geneva, Switzerland on 24 March 1990.

Correspondence to: Col. Dr. U. Imobersteg, Herzognacker 53 E, 3654 Gunten, BE, Switzerland.
} 
to gain access to the Iraqi side of the front line for the first time. In Bkhtaran, it was possible to examine and interrogate victims of presumed chemical attacks from the Baneh zone.

\section{Results}

In both 1984 and 1986, evidence was found confirming the use of Yperite, a skin poison, known also as Mustard Gas $\left.\left[\mathrm{ClCH}_{2} \mathrm{CH}_{2}\right)_{2} \mathrm{~S}\right]$ and the nerve gas, Tabun. The presence of Yperite and Tabun clearly was proven by the independent analyses carried out in both laboratories. Samples from a bomb fragment in Teheran and earth samples from near Basra that were analyzed using gas chromatography and mass spectography showed unmistakable evidence of Yperite. Medical examinations of some victims conducted in Iran demonstrated unequivocally that they had been wounded by Yperite. The victims had typical skin lesions, which are similar to thermal burns and require the same medical treatment. These wounds do not heal easily and require months of intensive medical care. Patients who had breathed fumes suffered severe pulmonary damage. Most such victims died. Survivors only have a slight chance of full recovery. Most cases develop chronic pulmonary problems which require prolonged, special hospital treatment. It was particularly horrible to witness the death of a four-year-old girl from Kurdistan, poisoned by Yperite. The 1987 team of experts was the first to be confronted with victims from among the Kurdish civilian population. The UN team came to the conclusion that there had been many civilian victims in Kurdistan. In an Iraqi hospital, the team was shown patients who in all probability had been poisoned by the substance phosgene $\left[\mathrm{COCl}_{2}\right]$, which causes severe pulmonary damage. There were many cases of pulmonary edema, including many that were fatal. By contrast, people from the Khorramshar region who had been caught in attacks with nerve gas Tabun apparently were on the way to full recovery after two weeks of hospitalization.

Compared to former investigations by the UN teams, the inspections conducted in 1987 and 1988 clearly indicated that there had been a substantial reduction in the number of victims of chemical warfare and a reduction in the severity of their injuries. This must be ascribed to the improved training and equipment of the combat troops. This is especially marked among the Revolutionary Guards who carried the main burden of the Iranian side of the war with Iraq.

\section{Discussion}

One Iranian physician commented that Yperite was the most dangerous chemical substance used in the Gulf, since it is capable of leading to death or lifelong chronic infirmity once it enters the bronchi. There is no known therapy against its effects. On the other hand, exposure to the nerve-attacking substance Tabun may be treated with good chances of survival if victims receive administration of atropine and oxygen within a short period following exposure.

This episode confirms that the use of chemical weapons is an especially gruesome form of warfare, particularly when it affects an unprotected civilian population. However, appropriate protective measures simply and effectively can reduce the impact of these weapons. It should be kept in mind that in combat zones around the Persian Gulf, the wearing of protective gear is hampered by the predominant high temperatures. In mid-April 1987, the recorded temperature in Khorramshar rose to 35$40 \mathrm{C}$ [95-104F] in the late morning.

\section{Conclusion}

The UN team of experts unanimously reached the conclusion that further technical and medical investigations cannot provide any new significant data. The proof already had been delivered regarding the use of these weapons in the Iran-Iraq war. In order to halt and finally put an end to the use of chemical weapons, political activity will be necessary to bring about an enforceable worldwide ban on the manufacture, storage, and use of these substances. Present restrictions only govern the first use of chemical weapons, thus permitting their manufacture and storage without violation of the Geneva Protocols. Without such international political pressure, there can be no doubt that combatants in other future hostilities will be tempted to try to influence the outcome through the use of chemical warfare. 


\section{7th WORLD CONGRESS ON EMERGENCY AND DISASTER MEDICINE}

\section{REGISTRATION FORM}

\section{(For Partielpants Only)}

\section{Advance Deadline}

Nov. 1, 1990
(Secretariat use only)

Reg. No.

Date Received

The meeting secretariat will make up a computerized list based on this form. Please write your name, affiliation and mailing address as you would like it to appear in the participants book and as an accurate mailing address for all information related to the congress.

(Type or print information in block letters)

Title: $\quad \square$ Prof. $\quad \square$ Dr. $\quad \square$ Mr. $\quad \square$ Ms. $\quad$ (check one)

Name:

Surname

First Name

Middle Initial

Mailing Address: $\quad \square$ home $\quad \square$ office

If you check "office" please include all information University, Hospital, Dept., Street, Company, Floor, Room Number, etc.

City:

Prov./State:

Country:

Telephone:

Facsimile (FAX):

Accompanying Person(s)
Mr.
Ms.
(check one)

Name:

Surname

First Name

Middle Initial

Name: 
Registration Fees (check category and fill in the amount to be paid)

\begin{tabular}{|c|c|c|c|c|c|}
\hline Category & $\begin{array}{c}\text { until: } \\
\text { Nov. 1, } 1990\end{array}$ & $\begin{array}{c}\text { until: } \\
\text { Doc. } 31,1990\end{array}$ & $\begin{array}{c}\text { after: } \\
\text { Jan. 1, } 1991\end{array}$ & $\begin{array}{l}\text { Number } \\
\text { of person(s) }\end{array}$ & $\begin{array}{l}\text { Amount to be } \\
\text { paid (see amount } \\
\text { based on date } \\
\text { of payment) }\end{array}$ \\
\hline $\begin{array}{l}\text { Active } \\
\text { Participants }\end{array}$ & $\$ 400$ & $\$ 500$ & $\$ 550$ & & \\
\hline $\begin{array}{l}\text { Accompanying } \\
\text { Person (Guest) }\end{array}$ & $\$ 150 \quad \square$ & $\$ 150 \quad \square$ & $\$ 150 \quad \square$ & & \\
\hline
\end{tabular}

\section{Canadian delegates please add 7\% Goods and Services Tax to registration fee}

Price includes proceedings and congress newsletter

\section{Method of Payment}

1. All payments should be made payable in Canadian dollars.

2. Bank draft, wire transfer or certified cheque, payable to the Medécine D'Urgence et de Catastrophe Congrès 1991.

This application will be validated and confirmed to you by Kush Medical Communications.

Please mail or fax this form to:

7th WCEDM Meeting Secretariat

Ms. Ursula Schwarz

Kush Medical Communications

6100 Montevideo Road, Unit 61

Mississauga, Ontario, Canada L5N 2N8

Telephone: (416) 821-3541

Facsimile: (416) 821-8863 